\title{
HISTORICAL ANALYSIS OF THE DAILY ENERGY REQUIREMENTS OF THE CADETS IN THE REPUBLIC OF BULGARIA
}

\author{
Pavlin Glushkov ${ }^{1}$, Simeon Simeonov ${ }^{2}$ \\ ${ }^{1}$ Ph.D., National Military University, Veliko Tarnovo, Bulgaria, pavlin_glushkov@mail.bg \\ ${ }^{2}$ Ph.D. Student, National Military University, Veliko Tarnovo, Bulgaria, sansiood@abv.bg
}

\begin{abstract}
The mission of Vasil Levski National Military University is to develop the students in moral, mental and physical aspects, to incorporate them to the ideals of patriotism, duty and honor, to form them as personalities and leaders with developed leader competences, capable of developing and implementing the scientific knowledge, to direct public and special structures in peacetime and during crises and to participate in national or multinational projects for keeping of security, peacekeeping and developing of the society.

Aim of the work: the aim of the research is to generalize the historical experience for the evaluation of the energy requirement of the military personnel from different national armies and to trace back in a historical aspect the tendencies of the daily energy requirement of the Cadets in the Republic of Bulgaria.

Methods: Study of literature sources of published data about the energy requirements of the military personnel from different armies and of the Cadets in the Republic of Bulgaria.

Conclusion: It's advisable to conclude researches energy requirements, connected with the military training and to implement the results of these researches as a base for the revision of the energy and nutrient values of the food rations, used in the nutrition of the students at Vasil Levski National Military University.
\end{abstract}

Keywords: daily energy requirements, norms, cadets, rational nutrition.

\section{INTRODUCTION}

The proper nutrition is one of the main factors for the good physical shape and the mental state of the Cadets, of the post-graduate students and of the soldiers, studying at "Vasil Levski" National Military University. The basic principle of the rational nutrition is that food must supply the needed quantity of energy, able to cover the quantity of the required energy for physical and mental activity. The consumed by the body energy can be covered only through intake of proteins, fats and carbohydrates from the food. The study of the daily energy requirement is ground for determination of the nutrient and energy values of the food rations of person, who are homogeneous according to their anthropometric data and are performing single activities and are living in similar conditions. 


\section{HISTORY OF THE STUDY OF THE ENERGY REQUIREMENTS OF THE MILITARY PERSONNEL}

The history of determination of the nutrient requirements and in particular of the energy requirements of the soldiers dates back to the 19th century. The feeding of the soldiers had usually been an object of interest for the authorities of medical insurance within the military units, because it affects directly the health of the soldiers and the effectiveness of their activities. In 1863 the responsibility for the feeding of the American Army was granted with a Law for Protection of Health during the Military Service and until the present moment, this law is still in force, despite of the numerous changes. According to these regulations the staff of the Medical Corps is responsible also for the nutrition of the soldiers (Nichev, 2017a, pp. 399-404; Terziev, Nichev, 2017b, pp. 627-630; Terziev, Nichev, 2017c, pp. 846-850; Terziev, Nichev, 2017d, pp. 631-635; Terziev, , Nichev, 2017e, pp. 667-671; Bertrandt, Kłos, Bertrandt, 2012a, pp. 57 - 60; Georgiev, 1953a, p. 9; Individual feeding ration, 2003a; Irinkov, Kolev, pp. 15-27; Klicka, Sherman, King, Friedl,. Askew; 1993a; Operational rations, 2012c; Schnakenberg 1995a, pp. 91-107; Sergey, 2011a; Stavrev, Sheytanov, Donev, 1969a, p. 189; Tharion et al. 2005a, 47-65).

About 1870 in Europe had been performed the first studies for measuring of the physiological load of the soldiers, wearing personal equipment with different weight and trainings had been conducted under different temperature ranges of the environment. Those and also the next researches, conducted in Europe and in the United States, had resulted in determination of the energy requirements of the military personnel, performing various activities, such as: drills, engineering equipment, movement of load etc. The quoted above researches demonstrate, that soldiers can be loaded with activities, needing energy in the range of 5000$6000 \mathrm{kcal} / \mathrm{daily}$, depending on the weight of the equipment and the outdoor temperature. The determination of the energy and alimentary needs of the soldiers at that time was based mainly on the average consumption of food. The food scheme, offered at the end of the First World War by the General Secretary of the Medical Corpse of the American Army, had been grounded on the results of the studies of the quantities of standardized food, consumed by the soldiers in 400 canteens during the period 1917-1918.

As noted in a historical reference about the development of the military norms of nutrition during the World War II, a nutrition standard is needed for the planning of a particular ration. The standard had to be based on requirements, suitable for the optimal feeding, not on minimal requirements. Besides that the standards for nutrient values ought to be grounded on the combined evaluations of the Feeding Authorities and not to be elaborated for single activities.

The results of the researches permit to determine the average energy value of the consumed food at a level of $3633 \mathrm{kcal}$, where the actual values are within the range from 3000 up to $4000 \mathrm{kcal}$. The next examination of the demand of energy by soldiers, based on calculations of the energetic values of food rations, was carried out in the United States in 1941. The research comprised totally several hundred units from the different sort and types of armies, military training centers etc. The average daily energy value of the consumed by soldiers food, amounted 3694 , varying from 3132 up to $4135 \mathrm{kcal}$. The highest energy value had been measured for the rations, distributed during the autumn season (September-November - 3960 $\mathrm{kcal})$, while the lowest energy value had been measured by the rations, distributed during the spring season (March-May - 3570 kcal).

The results don't differ significantly from those, obtained in 1917-1918. The carried out research in 1943 at 99 military canteens of the land troops of the American Army, comprising 130000 food rations had shown, that the average energy value of the daily ration amounts $3468 \mathrm{kcal}$, varying from 2774 up to $4644 \mathrm{kcal}$. In the spring of 1945 a study for determination of the energy value of the daily food ration in the American Army had been conducted. The average energy value of the food rations, granted to the soldiers, was $3744 \mathrm{kcal}$, varying from 3471 up to $4078 \mathrm{kcal}$. The average energy value, fixed in the research, was very close to the values, obtained for the food rations from the researches, which had been carried out during the First World War (3 $633 \mathrm{kcal})$ and the World War II (3 $694 \mathrm{kcal})$.

During the World War II the energy value of the food rations in the British Army was higher than the value of the American food rations and amounted $5127 \mathrm{kcal}$ in January 1942. Because of the excessively high weight of the rations, the energy value was reduced to $4562 \mathrm{kcal}$ in May 1942.

The results of the subsequent researches serve as a base for the revision of the alimentary standards of the American society; the changes in the recommendations for nutrition of the soldiers follow these changes.

After the World War II the term "minimal intake of nutrient substances" has been used for the basic alimentary standards in nutrition under stationary and field condition in the American army since 1947. The calorific standard of $3600 \mathrm{kcal} /$ daily for moderate climate has been increased up to $4400 \mathrm{kcal}$ for extremely 
cold areas. This regulation had been revised again in 1949 in order to add also standards of the female gender with corrections for active or sedentary way of activity. The first regulation concerning feeding standards, representing the tree types of armed forces, had been elaborated and adopted in 1968. In the feeding standards it's recommended, that the total intake of calories from sources of fats is $40 \%$ or less and that the menus mustn't contain more than $45 \%$ calories from sources of fats. The regulation had been changed again in 1969, where the basic changes affect the intake of calcium, which had been reduced to $800 \mathrm{mg}$ and for the reduction of the risk of heart diseases it was recommended to reduce the total contents of fats in the menus to $42 \%$ of the calories. The regulation had been revised once again in 1970 with the addition, that fats mustn't exceed $40 \%$ of the calories of the planned menus.

In 1985 the regulation was revised again and the average values for men and women are respectively 3200 and 2400 and depending on the different conditions may vary within the ranges $2800-3600 \mathrm{kcal} / \mathrm{daily}$ for men and 2000-2800 for women. The alimentary standards are defined as "daily basic levels of intake of nutritious substances", which are considered nowadays to be sufficient to cover the alimentary needs of practically all American servicemen, from 17 to 50 years old.

The research among the leading military forces in the world shows, that the energy contents of the feeding norms, adopted by STANAG 2937 for the Armies of the states-members of NATO, is $3600 \mathrm{kcal} / \mathrm{daily}$. The calorific value of the food in the American Army for the most popular individual ration MRE ${ }^{\mathrm{TM}}$ amounts 3900 $\mathrm{kcal} / \mathrm{daily}$. The values of the energy requirements of the soldiers from the Polish army during a typical training day depend on the sort and the character of the unit and lie within the range 3339.5 - 4651.6 $\mathrm{kcal} /$ daily, while the daily ration in Russia amounts $3595 \mathrm{kcal} /$ daily, in Great Britain the daily ration is 4050 $\mathrm{kcal} /$ daily, in Germany - $3950 \mathrm{kcal} /$ Daily, in France $-3875 \mathrm{kcal} /$ daily.

\subsection{Research of the Daily Energy Requirement of the Cadets in the Republic of Bulgaria}

In Bulgaria researches of the energy requirements of the soldiers in active service had been carried out already before the First World War and are connected mainly with the waged by the new country Balkan Wars. In 1907 the book "Soldiers' comrade" was published, where it was noted: "To one soldier it's due daily a sum, enough to buy one loaf of bread and some other products, costing 50 stotinki“. The energy and the alimentary value of the actually used rations were insufficient, what resulted in starvation among the soldiers.

The overall scientific progress in the 30-s of the XX century created the conditions to conduct physiological and social studies of the nutrition habits of the population and of the Army. They had a restricted size and were held mainly on the demand of and with the support of the progressive medical public in Bulgaria. During that period mainly under German influence, and in some cases under the influence of Western Europe several scientific hygiene norms of the military nutrition, water supply and accommodation had been fixed.

The first written data for implementation of the scientifically grounded nutrition norms and study of the energy requirement in the Bulgarian Army can be found in the school aid "Military nutrition". In result of implementation of the experience of the Central Nutrition Institute of the Soviet Union, of the geographic situation and of the national psychology in Bulgaria were approved the following nutrition norms:

Soldier ration - $3303 \mathrm{kcal}$;

Cadet ration $-3667 \mathrm{kcal}$;

Aviator ration $-4656 \mathrm{kcal}$ and

Hospital ration - $3389 \mathrm{kcal}$.

The observing of the given calorific value lies at the base for the elaboration of the weekly nutrition ration of the military personnel. In the school aid it's specified: „If a reduction of the calorific value of the ration is found out, a substitution of the low-calorific products with products with higher calorific value and to cover the calorific value norms".

According to the conducted researches in the Bulgarian Army in the 50-s of the XX century, the energy requirement of the soldier from the rifle-corps is, as follows: 
IJASOS- International E-Journal of Advances in Social Sciences, Vol. IV, Issue 12, December 2018

Table 1: Energy requirement of the soldiers from the rifle-corps during the 50-s of the XX century

\begin{tabular}{|l|l|l|l|}
\hline Sort of activity & $\begin{array}{l}\text { Energy } \\
\text { requirement for 1 } \\
\text { hour } \\
\text { kcal/h }\end{array}$ & $\begin{array}{l}\text { Duration } \\
\text { h }\end{array}$ & $\begin{array}{l}\text { Calorific } \\
\text { demand } \\
\text { kcal }\end{array}$ \\
\hline $\begin{array}{l}\text { Exercises for loading and unloading of } \\
\text { weapon outdoors }\end{array}$ & 476 & 0.25 & 119 \\
\hline Drills without weapon & 242 & 2 & 484 \\
\hline Drills with weapon & 375 & 2 & 750 \\
\hline Theoretical classes & 112 & 4 & 450 \\
\hline $\begin{array}{l}\text { Exercises for loading and unloading of } \\
\text { weapon indoors }\end{array}$ & 468 & 1 & 468 \\
\hline Self-training and self-service & 105 & 2 & 210 \\
\hline Feeding & 85 & 2 & 170 \\
\hline Rest after feeding & 83 & 1.75 & 145 \\
\hline Rest & 74 & 1 & 74 \\
\hline Sleep & 70 & 8 & 560 \\
\hline & Altogether & 24 & 3430 \\
\hline
\end{tabular}

The energy loss may vary in one or another direction, depending on the performed duties and tasks, yet it's specified, that the energy requirement of the soldiers in winter amounts $3550 \mathrm{kcal} / \mathrm{daily}$.

In 1957 the first Department of Military Epidemiology and Hygiene in the history of the Republic of Bulgaria was established, which became a significant scientific and research Centre within the structure of the Institute for Military Medicine since 1960. The questions of the influence of the environment and the military equipment on the organism were examined, also the effect of the Weapons of Mass Destruction on the soldiers, the combating of fatigue and the connected with them rational and preventive nutrition. In result of these researches it is concluded, that the energy requirement of the servicemen from the Bulgarian Army shows a tendency to reduction. In result of the conducted research during the period 1963-1965 in the three types of armed forces and in a University, it's found out, that the energy requirement in the Bulgarian Army is within the limits of $3500-4000 \mathrm{kcal} / \mathrm{daily}$. The following data support the above stated:

Rifle-corps:

- at the beginning of winter - $3450 \mathrm{kcal} / \mathrm{daily}$;

- in the months June and July - 3200-3800 kcal/daily;

- during long-lasting field trainings - up to $4150 \mathrm{kcal} /$ daily, in particular cases up to $5730 \mathrm{kcal} / \mathrm{daily}$.

Armored troops:

- during normal learning-combatant activity - from 3000 up to $3900 \mathrm{kcal} /$ daily, averagely $3610 \mathrm{kcal} /$ daily;

- in case of prolonged driving - from 3900 up to $4200 \mathrm{kcal} / \mathrm{daily}$.

Naval forces:

- In torpedo boats in ports - from 3500 up to $4000 \mathrm{kcal} /$ daily;

- During sailing on ships - up to $5000 \mathrm{kcal} / \mathrm{daily}$.

Air forces:

- for aviators from the propeller aviation - $3750 \mathrm{kcal} / \mathrm{daily}$;

- for aviators from the jet aviation - $3500 \mathrm{kcal} /$ daily;

- for technicians - kcal/daily.

These researches have an evaluative character and the obtained results serve as a basis for revision of the food rations of the soldiers. The results of the research are expressed in orders and regulations of the Ministry, regulating the nutrition of the personnel of the Bulgarian Army, of the Ministry of Defense and the subordinated to the Ministry of Defense structures and represent the only documents of its' kind to present date. The examined literature permits to generalize the caloricity of the daily intake of nutrient products by the Cadets during the years, and this caloricity is illustrated at Diagram 1. 


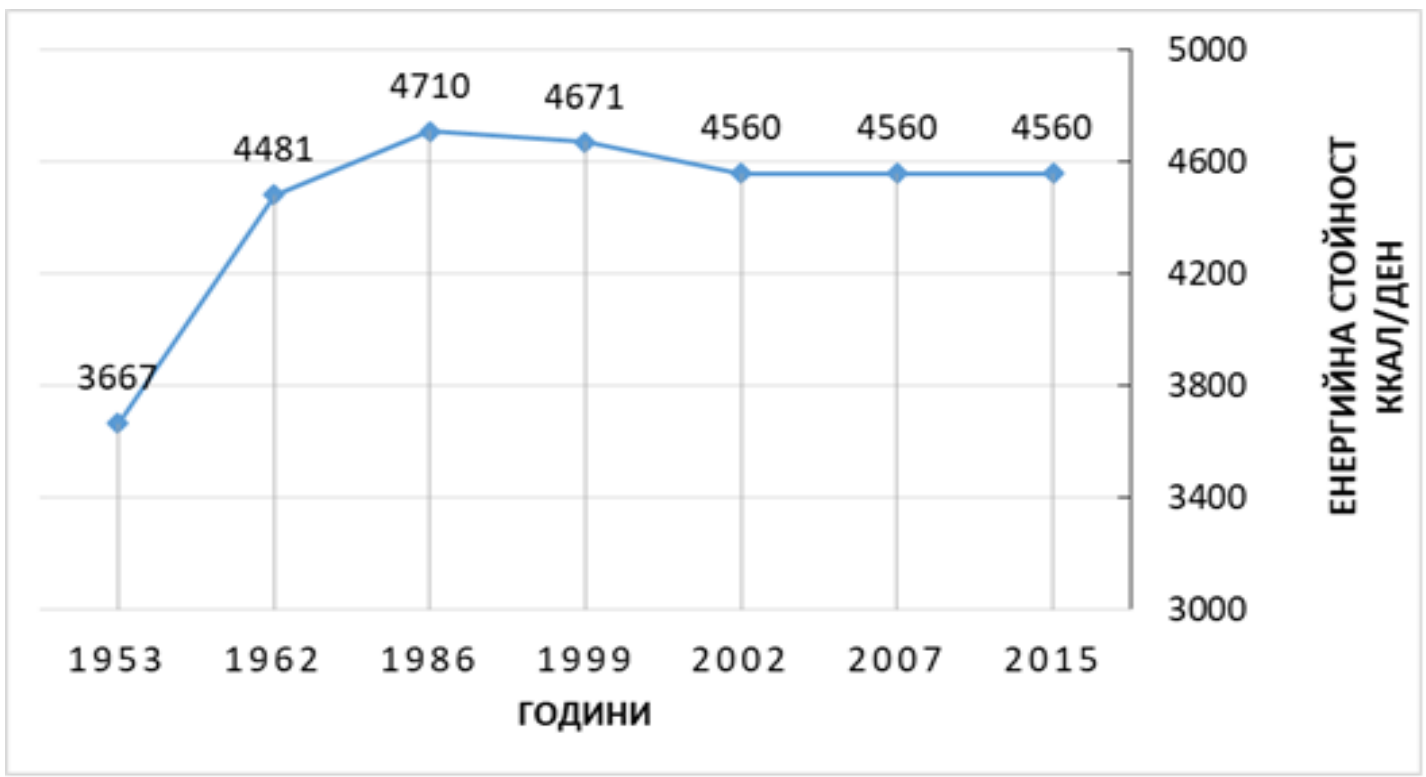

Diagram 1: Caloricity of the daily intake of nutrient products by the Cadets

During the years, the data from the tables of the regulating documents had first an obligatory, and later a recommendation character, but the contents of the major nutrient products for the assuring of a free feeding allows the easy calculation of the daily intake of energy by the cadets.

The values of the energy and of the substantial regulations for a balanced nutrition for a single day of nutrition of the military personnel depend on the type and the character of the unit, and are situated in the range 3500 - $6600 \mathrm{kcal} /$ daily (Table 2).

Table 2: Energy and substantial standards of a balanced nutrition for one feeding day

\begin{tabular}{|c|c|c|}
\hline \multirow{2}{*}{ Sort of activity } & \multicolumn{2}{|c|}{ Energy requirements } \\
\cline { 2 - 3 } & $\mathrm{kcal}$ & $\mathrm{kJ}$ \\
\hline During learning-combatant activity & $3500-3900$ & $14.64-16.32$ \\
\hline During field trainings & $4200-4600$ & $17.57-19.25$ \\
\hline Under camp conditions: & & \multirow{2}{*}{$12.55-13.81$} \\
-1 May until 30 September & $3000-3300$ & $17.57-19.25$ \\
-1 October until 30 April & $4200-4600$ & \\
& & \\
\hline During walking marches at the area: & $6000-6600$ & $25.10-27.61$ \\
-1 May until 30 September & $4200-4620$ & $17.57-19.33$ \\
-1 October until 30 April & & \\
\hline & & $14.64-15.06$ \\
\hline
\end{tabular}

In the examined literature there are no data about the levels of energy requirement of the Cadets from the Military Universities. Irinkov and Kolev examine the total energy value of the individual food package and suggest a classification of values of physical loading of military personnel during a 24-hours period according to the character of the performed activities and the connected with them level of physical activity. According to them the value of physical loading reflects the correlation between the consumed energy for the implementation of specific activities and the basic norm of metabolism of the human organism. The results of their study are listed in Table 3. 
IJASOS- International E-Journal of Advances in Social Sciences, Vol. IV, Issue 12, December 2018

Table 1: Values of the physical loading for the servicemen during the 24-hours period (adapted according to Irinkov and Kolev)

\begin{tabular}{|c|c|c|c|}
\hline $\begin{array}{c}\text { Character of activities of the military } \\
\text { personnel }\end{array}$ & $\begin{array}{c}\text { Physical } \\
\text { activity level }\end{array}$ & $\begin{array}{c}\text { Value of the physical } \\
\text { loading during the 24- } \\
\text { hours period }\end{array}$ & $\begin{array}{c}\text { Energy value of the } \\
\text { individual food } \\
\text { package, kcal }\end{array}$ \\
\hline $\begin{array}{c}\text { Work in the headquarters } \\
\text { Study-combatant activity at the territory } \\
\text { of the country }\end{array}$ & Insignificant & 1,69 & 5127 \\
\hline $\begin{array}{c}\text { Participation in operations, different } \\
\text { from war and reserve for battle } \\
\text { operations }\end{array}$ & High & $1,70-1,99$ & $5128-6036$ \\
\hline $\begin{array}{c}\text { Participation in battle operations as } \\
\text { part of the major forces }\end{array}$ & Very high & 2,00 & 7281 \\
\hline $\begin{array}{c}\text { Servicemen from the specialized forces } \\
\text { Extreme }\end{array}$ & over 2,40 & over 7281 \\
\hline
\end{tabular}

The researches of the leading scientists in the sphere of military nutrition science are oriented mainly towards the energy requirement of the soldiers during combat activities, of the soldiers from the specialized forces, during field and tactical trainings. The analysis of the accessible reveals data about the energy requirement during the training of the Cadets at the West Point Military Academy in the United States and at the Polish Military Universities. The summarized data of the energy requirement at the mentioned above Universities and the secured through the food energy requirement of the Cadets at Vasil Levski NMU is shown in Table 4.

Table 2: Summarized data of the energy requirement in the Military Universities

\begin{tabular}{|c|c|c|}
\hline Military University & $\begin{array}{c}\text { Average daily energy } \\
\text { requirement } \\
{[\mathrm{kcal}]}\end{array}$ & $\begin{array}{c}\text { Average daily energy } \\
\text { requirement } \\
{[\mathrm{MJ}]}\end{array}$ \\
\hline $\begin{array}{c}\text { U. S. West Point Military } \\
\text { Academy, men }\end{array}$ & 3200 & 13,4 \\
\hline $\begin{array}{c}\text { U. S. West Point Military } \\
\text { Academy, women }\end{array}$ & 2400 & 10,0 \\
\hline $\begin{array}{c}\text { Students at the Polish Military } \\
\text { Academy }\end{array}$ & 3535,0 & 14,51 \\
\hline $\begin{array}{c}\text { Students at the Polish Military-Medical } \\
\text { Academy }\end{array}$ & 3339,5 & 13,99 \\
\hline $\begin{array}{c}\text { Students at the Polish Military Technical } \\
\text { Academy }\end{array}$ & 3737,3 & 15,66 \\
\hline $\begin{array}{c}\text { Students at Vasil Levski } \\
\text { National Military University }\end{array}$ & 4560,00 & 19,09 \\
\hline
\end{tabular}

The submitted data illustrate the big difference between the summarized daily energy requirements of the Cadets from Vasil Levski NMU and the examined Military Universities (Terziev, Nichev, 2017f, p.164; Terziev, Nichev, 2017g, pp.915-919; Terziev, Nichev, Bogdanov, 2017h, pp. 469-475; Terziev, Nichev, Bogdanov, 2017i, pp.671-677; Nichev, 2017j, str. 121-128; Nichev, 2017k, pp. 129-135; Kanev, Terziev, 2017l, pp.413-423; Kanev, Terziev. 2017m, pp. 595-606; Sotirov, Terziev, 2015a, str. 197-207; Sotirov, 
Terziev, 2015b, p.25; Terziev, 2017n, pp. 893-908; Terziev, 2016a, s.84-90; Terziev. 2017o, p.252; Terziev, 2017p, pp.22-28; Terziev, Vezieva, Arabska, 2016b, str.106-121; Terziev, Manolov, 2016c, pp.15-20; Terziev, Minev, Sotirov, Ivanov, 2016d; Terziev. Kanev, 2017q, pp.733-742; Terziev, Madanski, 2017v, pp.917-937; Terziev, Madanski, 2017r, pp.28-36; Terziev, Madanski, 2017s, pp.610-625; Terziev, Madanski, Kanev, 2017t, pp.575-594; Terziev, Madanski, Kanev, 2017u, pp.396-415; Terziev, Madanski, Kanev, 2017v, pp.1331-1346; Terziev, Madanski, Kanev, 2017w, pp.1355-1372; Terziev, Madanski, Kanev, 2017x, pp.1380-1393; Terziev, Nichev, 2016e, pp.101-106; Terziev, Nichev, 2017y, pp.661-666; Banabakova, Georgiev, 2018a, pp. 46-51; Banabakova, Georgiev, 2018b, pp. 462-467; Terziev, Manolov, 2016f, pp.307318; Terziev, Manolov, 2016g, pp.15-29; Terziev, Manolov, 2016h, s.96-106; Terziev, Manolov, 2016i, pp.570-575; Terziev, Manolov, 2016j, pp.9-13).

\section{CONCLUSION}

At the present moment the service at the Bulgarian Armed forces is a professional activity, that's why the results of the researches of the energy requirements during the study at Vasil Levski NMU, which were used as a basis for determination of the energy values of the food rations and of the nutrition in general, have lost a part of their importance. It's reasonable to conduct researches of the energy expenditures, connected with the military training and to use the results of these researches as a base for determination and/ or revision of the energy and nutritional values of the food rations, used for the nutrition of the Cadets, of the Postgraduate Students and of the soldiers in Vasil Levski National Military University.

\section{REFERENCE LIST}

Nichev, N., (2017a). Research on the Preparation and Professional Realization of Newly Appointed Logistics Officers. // The $23^{\text {rd }}$ International conference Knowledge-Based Organization, Volume XXIII No 2, Nicolae Balcescu Land Forces Academy, Sibiu, Romania, 2017, pp. 399-404.

Terziev, V., Nichev, N. (2017b). Analysis of the Environment for Military Educational System Functioning and Its Impact on the Preparation of Cadets for Military Professional Activities in the Republic of Bulgaria. // Proceedings of $4^{\text {th }}$ International Conference on Education, Social Sciences and Humanities, 10-12 July 2017, OCERINT, Dubai, UAE, pp. 627-630, ISBN: 978-605-82433-1-6.

Terziev, V., Nichev, N. (2017c). Research on the Management Skills and Abilities Acquired in the Military Education System. // Central Bohemia University International Conference Proceedings 2017, Innovations in Science and Education, March 22-24, Published by Central Bohemia University, 2017, pp. 846-850, ISSN 1805-997X (Print), ISSN 1805-9961 (Online).

Terziev, V., Nichev, N. (2017d). Some Aspects on Forming Preparedness of Logistics Military Officers for Management Activities. // Proceedings of 4th International Conference on Education, Social Sciences and Humanities, 10-12 July 2017, OCERINT, Dubai, UAE, pp. 631-635, ISBN: 978-605-82433-1-6.

Terziev, V., Nichev, N. (2017e). Streamlining Management Solutions for Economic, Effective and Efficient Spending of Resources for Security and Defense. Proceedings of $4^{\text {th }}$ International Conference on Education, Social Sciences and Humanities, 10-12 July 2017, OCERINT, Dubai, UAE, pp. 667-671, ISBN: 978-605-82433-1-6.

Bertrandt, J., Anna Kłos, A., Bertrandt, B. (2012a). Energy expenditure as the basis for determination of nutritional demand in soldiers. Military Pharmacy and Medicine, Volume V, No. 4, 2012, pp. 57 - 60.

Georgiev, K. I. (1953a). Military nutrition, educational aid, Ministry of Defense, State M. Publsihing, Sofia., 1953 , p. 9.

Individual feeding ration (2003a). TU 9194-461-04605473-03, Ministry of Defense, Russian Federation, 2003.

Irinkov, V., Kolev, N. (2012b). Problems of nutrition of the servicemen participating in the contemporary operations and directions of their settling. Military Gazette, Issue 2, 2012, pp. 15-27.

Mary V. Klicka, E. Sherman,Nancy King, Karl E. Friedl, Eldon W. Askew. (1993a). Nutritional Assessment of Cadets at the U.S. Military Academy: Part 2. Assessment of Nutritional Intake. Technical Report No.T94-1, United States Army Medical Research Development Command, Natick, Massachusetts, 
IJASOS- International E-Journal of Advances in Social Sciences, Vol. IV, Issue 12, December 2018

1993.

Operational rations of the department of defense. (2012c). DoD Combat Feeding Directorate: NATICK PAM 30-25, 2012.

Schnakenberg D.D. (1995a). Nutritional Criteria for Development and Testing of Military Field Rations, A Historical Perspective. In: Not Eating Enough: Overcoming Underconsumption of Military Operational Rations. National Academy Press, Washington, D.C. 1995, pp. 91-107.

Sergey Yuferev, Na hlebom edinim. (2011a). // Publishing "Military observation", 2011, https://topwar.ru/8940-ne-hlebom-edinym.html, visited on 20.10.2017.

Stavrev, P., Sheytanov. M., Donev, D. (1969a). Military Hygiene, // Ministry of Defense, MP, Sofia, 1969, p. 189.

W.J. Tharion et al. (2005a). Energy requirements of military personnel. // Appetite 44 (2005) 47-65.

Terziev, V., Nichev, N. (2017f). Developing the readiness for the organizational activity of the cadets. // CBU International Conference Book of Abstracts, March 22-24, 2017, Prague, Czech Republic, Innovations in Science and Education, ISBN 978-80-88042-09-9, p.164.

Terziev, V., Nichev, N. (2017g)/ Developing the readiness for the organizational activity of the cadets. // CBU International Conference Proceedings 2017, March 22-24, Prague, Czech Republic, Innovations in Science and Education, 2017, SSN 1805-997X (Print), ISBN 978-80-88042-07-5 (Print edition), pp.915-919.

Terziev, V., Nichev, N., Bogdanov, P. (2017h). Comparative analysis of the formation of military professional skills in the cadets to be trained in logistics specializations. // IJAEDU- International E-Journal of Advances in Education, International Organization Center of Academic Research, www.ocerint.org, 3, 2017, N 9, pp. 469-475, (INT) e-ISSN: 2411-18.

Terziev, V., Nichev, N., Bogdanov, P. (2017i). Comparative analysis of the formation of military professional skills in the cadets to be trained in logistics specializations. // Proceedings of ADVED 2017- 3rd International Conference on Advances in Education and Social Sciences 9-11 October 2017- Istanbul, Turkey, 2017, ISBN: 978-605-82433-0-9, pp.671-677.

Nichev, N. (2017j). Ofsetna politika na stranite ot Evropeyskiya Sayuz. Spisanie za nauka „Novo znanie”, Akademichno izdatelstvo "Talant“, Visshe uchilishte po agrobiznes i razvitie na regionite, Plovdiv, Vol 6, No 1, 2017, str. 121-128, ISSN 2367-4598 (Online), ISSN 1314-5703 (Print) (Ничев, Н. Офрсетна политика на страните от Европейския Съюз. Списание за наука „Ново знание”, Академично издателство „Талант“, Висше училище по агробизнес и развитие на регионите, Пловдив, Vol 6 , No 1, 2017, стр. 121-128, (Online) ISSN 2367-4598, (Print) ISSN 1314-5703).

Nichev, N. (2017k). Perspektivi za izpolzvane na ofsetnite sdelki. Spisanie za nauka „Novo znanie”, Akademichno izdatelstvo „Talant“, Visshe uchilishte po agrobiznes i razvitie na regionite - Plovdiv, Vol 6, No 1, 2017, pp. 129-135, (Online) ISSN 2367-4598, (Print) ISSN 1314-5703 (Ничев, Н. Перспективи за използване на офсетните сделки. Списание за наука „Ново знание”, Академично издателство „Талант“, Висше училище по агробизнес и развитие на регионите Пловдив, Vol 6, No 1, 2017, pp. 129-135, (Online) ISSN 2367-4598, (Print) ISSN 1314-5703).

Kanev, D.,Terziev. V. (2017I). Behavioral economics: development, condition and perspectives. // IJASOSInternational E-Journal of Advances in Social Sciences, Vol. III, Issue 8, pp.413-423, e-ISSN: 2411$183 \mathrm{X}$.

Kanev, D.,Terziev. V. (2017m). Behavioral economics: development, condition and perspectives. // Proceedings of SOCIOINT 2017- 4th International Conference on Education, Social Sciences and Humanities 10-12 July 2017- Dubai, UAE, pp. 595-606, ISBN: 978-605-82433-1-6.

Sotirov, B., Terziev, V. (2015a). Predizvikatelstva i perspektivi pred obuchenieto po tehnologichni distsiplini. // Parva mezhdunarodna nauchna konferentsiya „Predizvikatelstva pred savremennite organizatsii, svarzani s postigane na ustoychivost - znanie i inovatsii v upravlenieto i funktsioniraneto",Plovdiv. ISBN 978-619-7246-04-9 (DVD), ISBN 978-619-7246-06-3 (e-book), str. 197-207, Сотиров, Б., Терзиев, В. Предизвикателства и перспективи пред обучението по технологични дисциплини. // Първа международна научна конференция „Предизвикателства пред съвременните организации, свързани с постигане на устойчивост - знание и иновации в управлението и функционирането“, 12 декември 2015 г., Пловдив, 2015, ISBN 978-619-7246-04-9 (DVD), ISBN 978-619-7246-06-3 (e-book), стр.197-207. 
IJASOS- International E-Journal of Advances in Social Sciences, Vol. IV, Issue 12, December 2018

Sotirov, B., Terziev, V. (2015b). Challenges and perspectives to the training in technological subjects. // Book of Abstracts: First International Scientific Conference „Sustainability Challenges in Modern Organizations - Knowledge \& Innovation in Management \& Operation", p.25, ISBN 978-619-7246-03-2 (DVD), ISBN 978-619-7246-05-6 (e-book).

Terziev, Venelin. (2017n). National security of the republic of Bulgaria. // The Chinese Journal of International Politics, 10, 2017, N 4 (2), pp. 893-908, ISSN 1750-8916, Source Normalized Impact per Paper (SNIP): 1.901 SCImago Journal Rank (SJR): 1.238 Impact factor: 1.594 5-Yr impact factor: 1.747.

Terziev. V. (2016a). Human resource management systems in security and defense: social policies for social activities. // XXXII Mezhdunarodnaya nauchno-prakticheskaya konferentsiya, Evraziyskiy soyuz uchenayh (ESU), Ezhemesyachnayy nauchnayy zhurnal № 12 (33)/ 2016 Chasty 1, Moskva 30.12.2016g., s.84-90, ISSN 2411-6467 (Terziev, Venelin. Human resource management systems in security and defense: social policies for social activities. // XXXII Международная научнопрактическая конфреренция, Евразийский союз ученых (ЕСУ), Ежемесячный научный журнал № 12 (33)/ 2016 Часть 1, Москва 30.12.2016г., 2016, с.84-90, ISSN 2411-6467).

Terziev. V. (20170). Entry Opportunities in the Bulgarian Military - Educational System and Ensuring of Civil Rights. // 3rd Central and Eastern European LUMEN International Scientific Conference New Approaches in Social and Humanistic Sciences 8-10 June 2017, Chisinau, Republic of Moldova, 2017, ISBN: 978-973-166-461-3, p.252.

Terziev. Venelin. (2017p). National security of the republic of Bulgaria. // International Journal of Management and Applied Science, 3, 2017, N 4, ISSN: 2394-7926, pp.22-28.

Terziev, V., Vezieva, D., Arabska, E. (2016b). Balgarskite universiteti i vazmozhnostite na Operativna programa „Nauka i obrazovanie za inteligenten rastezh". // Mezhdunarodna nauchna konferentsiya „Obrazovanie, nauka, ikonomika i tehnologii“ 23-24 yuni 2016 g. Akademichno spisanie „Upravlenie i obrazovanie", 12, 2016, N 1, ISSN 1312-6121, str.106-121 (Терзиев, В., Везиева, Д., Арабска, Е. Българските университети и възможностите на Оперативна програма „Наука и образование за интелигентен растеж". // Международна научна конференция „Образование, наука, икономика и технологии“ 23-24 юни 2016 г. Академично списание „Управление и образование“, 12, 2016, N 1 , ISSN 1312-6121, стр.106-121).

Terziev, V., Manolov, D. (2016c). Creation of good organizational environment for scientific research activity (Създаване на добра организационна среда за научноизследователска дейност) // Актуальные проблемы глобализации, Салоники, Греция (Actual problems of globalization, August 29, 2016, Thessaloniki, Greece), Scientific journal «Economics and Finance», Actual problems of globalization Collection of scientific articles, 2016, ISBN 978-617-7214-34-1, pp.15-20.

Terziev, V., Minev, R., Sotirov, B., Ivanov, K. (2016d). Vazmozhnosti za izgrazhdane na tsentar za kompetentnost $v$ Severen tsentralen rayon na Republika Balgariya. // Godishna universitetska nauchna konferentsiya, 20-21 oktomvri 2016 g. NVU „Vasil Levski“- Veliko Tarnovo. Sbornik dokladi tom 2, Nauchni napravleniya „Prirodomatematicheski nauki” i „Tehnicheski nauki”, ISSN 1314-1937.

Terziev. V., Kanev, D. (2017q). Education and Behavioural Failures. // Proceedings of ADVED 2017- 3rd International Conference on Advances in Education and Social Sciences 9-11 October 2017- Istanbul, Turkey, pp.733-742, ISBN: 978-605-82433-0-9.

Terziev, V, Madanski, V. (2017v). Development of military education system in Bulgaria. // American Journal of Education, The University of Chicago Press, 2017, 123, 2017, N 4 (2), ISSN: 0195-6744, pp.917937.

Terziev, V, Madanski, V. (2017r). Guidelines for development of military education system in Bulgaria (Nasoki za razvitie na voennoobrazovatelnata sistema na Balgariya). // Topical questions of contemporary science, United States of America 2017, ISBN 978-0-9988732-1-3, pp.28-36.

Terziev, V, Madanski, V. (2017s). Guidelines for development of military education system in Bulgaria. // Proceedings of the VII International Academic Congress "Fundamental and Applied Studies in EU and CIS Countries" (United Kingdom, Cambridge, England, 26-28 February 2017), Cambridge University Press, ISBN: 978-0-875-83597-4, 7, 2017, pp.610-625.

Terziev, V, Madanski, V., Kanev, D. (2017t). Entry opportunities in the bulgarian military-educational system and ensuring of civil rights. // Proceedings of SOCIOINT 2017- $4^{\text {th }}$ International Conference on Education, Social Sciences and Humanities 10-12 July 2017- Dubai, UAE, 2017, ISBN: 978-605- 
IJASOS- International E-Journal of Advances in Social Sciences, Vol. IV, Issue 12, December 2018

82433-1-6, pp.575-594.

Terziev, V, Madanski, V., Kanev, D. (2017u). Entry opportunities in the bulgarian military-educational system and ensuring of civil rights. // IJAEDU- International E-Journal of Advances in Education, 3, 2017, N 8 , e-ISSN:2411-1821, pp.396-415.

Terziev, V, Madanski, V., Kanev, D. (2017v). Entry opportunities in the Bulgarian military-educational system. // Sport, Education and Society, Taylor \& Francis, 22, 2017, N 8(2), Source Normalized Impact per Paper (SNIP): 1.459 SCImago Journal Rank (SJR): 1.005 Impact factor: 1.269 Ranking: 60/230 (Education \& Educational Research), 20/44 (Hospitality, Leisure, Sport and Tourism), 51/82 (Sport Sciences), Print ISSN: 1357-3322, Online ISSN: 1470-1243, pp.1331-1346.

Terziev, V, Madanski, V., Kanev, D. (2017w). Condition and capabilities of the military-educational system of the Republic of Bulgaria. // Sport, Education and Society, Taylor \& Francis, 22, 2017, N 8(2), Source Normalized Impact per Paper (SNIP): 1.459 SCImago Journal Rank (SJR): 1.005 Impact factor: 1.269 Ranking: 60/230 (Education \& Educational Research), 20/44 (Hospitality, Leisure, Sport and Tourism), 51/82 (Sport Sciences), Print ISSN: 1357-3322 Online ISSN: 1470-1243, pp.1355-1372.

Terziev, V, Madanski, V., Kanev, D. (2017x). Directions for improvement of the military-educational system and its contribution for strengthening national security and the defence of the country. // Sport, Education and Society, Taylor \& Francis, 22, 2017, N 8(2), Source Normalized Impact per Paper (SNIP): 1.459 SCImago Journal Rank (SJR): 1.005 Impact factor: 1.269 Ranking: 60/230 (Education \& Educational Research), 20/44 (Hospitality, Leisure, Sport and Tourism), 51/82 (Sport Sciences), Print ISSN: 1357-3322 Online ISSN: 1470-1243, pp.1380-1393.

Terziev, V., N.Nichev. (2016e). Икономически характеристики на офсетните сделки с отбранителни продукти (Economic characteristics of offset transactions with defense products). // Scientific journal „Economics and Finance“, Problems of development modern science: Theory and practice Collection of scienfic articles, 2016, ISBN 978-617-7214-33-4, pp.101-106.

Terziev. V., N.Nichev. (2017y). Main features of the offsets in defense trade. Proceedings of SOCIOINT 2017- $4^{\text {th }}$ International Conference on Education, Social Sciences and Humanities 10-12 July 2017Dubai, UAE, 2017, ISBN: 978-605-82433-1-6, pp.661-666.

Banabakova, V., Georgiev, M. (2018a). Military professional forming of the cadets at Vasil Levski National Military University. // IJAEDU- International E-Journal of Advances in Education, April 2018, Turkey, International Organization Center of Academic Research, www.ocerints.org, Istanbul, Turkey, 2018, pp. 46-51, 4, 2018, N 10, e-ISSN: 2411-1821.

Banabakova, V., Georgiev, M. (2018b). Military professional forming of the cadets at Vasil Levski National Military University. // Proceedings of INTCESS2018- 5th International Conference on Education and Social Sciences 5-7 February 2018- Istanbul, Turkey, International Organization Center of Academic Research, www.ocerints.org, Istanbul, Turkey, 2018, pp. 462-467, ISBN 978-605-82433-2-3.

Terziev, V., Manolov, D. (2016f). Методика за планиране на снабдяването с вещево имущество в ресурсно ограничена среда (Methodology for planning of supply with clothes, shoes and equipment in Bulgarian armed forces). // Tenth International Scientific Conference The power of knowledge, 7-9 October 2016, Agia Triada, Republic of Greece, Knowledge International Journal Scientific papers, Institute of Knowledge Management, Skopje, 14, 2016, N 1, ISSN 1857-92, pp.307-318.

Terziev, V., Manolov, D. (2016g). Изграждане на капацитет в публичните служби за заетост (Сapacity building in public employment services). // Scientific journal „Economics and Finance“, Problems of development modern science: Theory and practice - Collection of scienfic articles, 2016, ISBN 978617-7214-33-4, pp.15-29.

Terziev, V., Manolov, D. (2016h). Particular features of carrying out a procurement procedure at the Ministry of Defense. // XIII Mezhdunarodnaya nauchno-prakticheskaya konferentsiya „Sotsialynoekonomicheskie nauki i gumanitarnaye issledovaniya", g. Novosibirsk, 28 lyunya, 25 lyulya 2016 g., ISBN 978-5-00068-616-4, s.96-106, Terziev, V., Manolov, D. Particular features of carrying out a procurement procedure at the Ministry of Defense. // XIII Международная научно-практическая конференция „Социально-экономические науки и гуманитарные исследования”, г. Новосибирск, 28 Июня, 25 Июля 2016 г., ISBN 978-5-00068-616-4, с.96-106.

Terziev, V., Manolov, D. (2016i). Систематизация на първична информация в статистически редове в планирането на снабдяването с вещево имущество в Българската армия (Systematization of original information in statistical rows in the planning of supply with clothes and equipment in Bulgarian 
armed forces). // Tenth International Scientific Conference The power of knowledge , 7-9 October 2016, Agia Triada, Republic of Greece, Knowledge International Journal Scientific papers, Institute of Knowledge Management, Skopje, 14, 2016, N 2, ISSN 1857-92, pp.570-575.

Terziev, V., Manolov. D. (2016j). Analysis of NATO logistics handbook. // Scientific journal „Economics and finance“, Verlag SWG imex GmbH, Nurnberg, Deutshland, Trends in der Entwicklung der nationalen und internationalen Wissenschaft, 2016, ISBN 978-617-7214-44-0, pp.9-13. 